hydrate and its evaporation to dryness. The ether residue, after separation, is poured into a test tube and about $5 \mathrm{~cm}$. of water containing a small amount of ferric chloride are added. The test tube is then shaken vigorously and the ether and water layers allowed to separate. The presence of salicylic acid is indicated by a violet coloration of the water layer.

Chemical Laboratory, Department of Health

$$
\text { NEW YORK CITY }
$$

\section{BOUILLON CUBES}

By F. C. Cooz

Received September 13, 1913

INTRODUCTION

Bouillon cubes consist of a large amount of common salt mixed with varying amounts of meat and plant extract, a small per cent of fat, and a little condiment. Some of the products sold under the name "bouillon cubes" contain but a small per cent of meat stock or extractives, and are not entitled to the term "bouillon" unless it is modified. They are extensively advertised as capable of making a stimulating and appetizing hot drink simply by being dissolved in hot water. They have, therefore, a legitimate place among óur dietary accessories.

Several brands of these cubes have appeared on the of the Association of Official Agricultural Chemists, ${ }^{1}$ total creatinin by the Benedict-Myers ${ }^{2}$ autoclave method, and precipitation with alcohol in hydrochloric acid solution was carried out according to Rippetoe's method, ${ }^{3}$ which is as follows:

Rippetoe's Method.-Transfer Io cc. of an aqueous - solution containing 2 grams of the sample to a 200 cc. glass-stoppered measuring cylinder, add I.2 cc. of I 2 per cent hydrochloric acid, mix and add absolute alcohol to the $200 \mathrm{cc}$. mark, shake and let stand several hours at 20 to $25^{\circ} \mathrm{C}$. If necessary make to mark, filter, and determine total nitrogen in I00 cc. of filtrate.

The acidity figures were obtained by titrating one gram of the sample dissolved in roo cc. of water with twentieth-normal sodium hydroxide, using phenolphthalein as indicator. The results obtained on the ten samples of cubes analyzed are given in Tables $I$ and II.

The water content of the cubes examined was under 5 per cent and the ether extract figures varied from I to 4.58 per cent. These last figures represent the amount of fat added to these cubes during the process of manufacture. The ash, which is largely sodium chloride, varied from 50 to 74 per cent. A large amount of sodium chloride is necessary to give a salty taste to the cup of water in which the cube is dissolved, and

Table I-ANalysis of Bouillon Cubes-Original Basis

\begin{tabular}{|c|c|c|c|c|c|c|c|c|c|c|c|}
\hline $\begin{array}{l}\text { Sample } \\
\text { No. }\end{array}$ & Brand & $\begin{array}{c}\text { • } \\
\text { Solids } \\
\text { Per cent }\end{array}$ & $\begin{array}{l}\text { Organic } \\
\text { material } \\
\text { Per cent }\end{array}$ & $\begin{array}{l}\text { Ether } \\
\text { extract } \\
\text { Per cent }\end{array}$ & $\begin{array}{c}\text { Ash } \\
\text { Per cent }\end{array}$ & $\begin{array}{l}\text { Total } \\
\text { chlorine as } \\
\text { sodium } \\
\text { chloride } \\
\text { Per cent }\end{array}$ & $\begin{array}{c}\text { Total } \\
\text { phosphoric } \\
\text { acid }\left(\mathrm{P}_{2} \mathrm{O}_{5}\right) \\
\text { Per cent }\end{array}$ & $\begin{array}{l}\text { Acidity } \\
\text { (cc. twentieth- } \\
\text { normal } \\
\text { sodium } \\
\text { hydroxid } \\
\text { per } 1 \text { gram) }\end{array}$ & $\begin{array}{c}\text { Total } \\
\text { nitrogen } \\
\text { Per cent }\end{array}$ & $\begin{array}{c}\text { Nitrogen } \\
\text { precipitated } \\
\text { by absolute } \\
\text { alcohol in } \\
\text { hydrochloric } \\
\text { acid } \\
\text { Per cent }\end{array}$ & $\begin{array}{c}\text { Total } \\
\text { crea- } \\
\text { tinin } \\
\text { Per } \\
\text { cent }\end{array}$ \\
\hline 1977 & Behrend & 96.60 & 22.86 & 1.93 & 73.74 & 72.13 & 1.02 & 6.20 & 2.19 & 0.13 & 0.84 \\
\hline 1978 & Oxo & 95.06 & 25.31 & 3.10 & 69.75 & 65.00 & 1.51 & 6.50 & 2.97 & 0.86 & 1.07 \\
\hline 1979 & Steero & 96.05 & 28.41 & 1.20 & 67.64 & 62.15 & 1.83 & 9.15 & 3.62 & 0.76 & 1.67 \\
\hline 1980 & Burnham & 96.87 & 41.94 & 1.00 & 54.93 & 52.90 & 0.58 & 6.10 & 2.11 & 0.05 & 0.88 \\
\hline 1981 & Sunbeam & 95.73 & 45.23 & 1.44 & 50.50 & 49,26 & 0.54 & 7.30 & 2.36 & 0.02 & 0.92 \\
\hline 1982 & Armour & 96.05 & 26.48 & 0.96 & 69.57 & 67.44 & 0.62 & 6.00 & 2.79 & 0.17 & 1.07 \\
\hline 1983 & Morris & 96.77 & 33.00 & 3.79 & 63.77 & 59.17 & 1.69 & 9.68 & 3.67 & 0.56 & 1.07 \\
\hline 1984 & Standard & 95.81 & 21.76 & 4.19 & 74.05 & 72.22 & 0.48 & 5.01 & 2.09 & 0.07 & 0.50 \\
\hline 1985 & Liggitt & 96.00 & 21.91 & 4.58 & 74.09 & 71.98 & 0.41 & 4.75 & 2.11 & 0.05 & 0.49 \\
\hline 1986 & Knorr & 95.44 & 26.24 & 4.57 & 69.20 & 65,00 & 1.55 & 7.40 & 3.20 & 0.91 & 1.38 \\
\hline
\end{tabular}

American market in the past five years, most of them manufactured in this country, and some imported from Germany. Many are wrapped in tin foil, while others are wrapped in paraffin paper, and occasionally a brand of cubes is found in both foil and paper. As the moisture content is low and a large amount of salt is present, they will keep indefinitely, although certain makes tend to lose their form during warm weather.

The bouillon cubes which are reported in this paper were collected on the New York market in I9I 2.

\title{
METHODS OF ANALYSIS
}

The samples were prepared for analysis by grinding fifteen to twenty cubes in a mortar as thoroughly as possible and placing the composite paste in small screw-cap jars. The solids were obtained by drying to constant weight in vacuo at $65^{\circ} \mathrm{C}$. The ash, sodium chloride, phosphoric acid $\left(\mathrm{P}_{2} \mathrm{O}_{5}\right)$, nitrogen, and ether extract were determined by the methods

1 Physiological Chemist, Animal Physiological Chemistry Laboratory, Bureau of Chemistry.

to furnish body to the cube. Sudendorf analyzed I 8 samples of cubes bought on the market at Hamburg, Germany, and two samples prepared in his

Table II-Analysis of Bouillon Cubes-Water, Fat, and Ash-FreE

\begin{tabular}{|c|c|c|c|c|c|}
\hline \multicolumn{6}{|c|}{ BASIS } \\
\hline $\begin{array}{c}\text { Sample } \\
\text { No. }\end{array}$ & Brand & $\begin{array}{c}\text { Phosphoric } \\
\text { acid }\left(\mathrm{P}_{2} \mathrm{O}_{5}\right) \\
\text { Per cent }\end{array}$ & $\begin{array}{l}\text { Total } \\
\text { nitrogen } \\
\text { Per cent }\end{array}$ & $\begin{array}{l}\quad \text { Total } \\
\text { creatinin } \\
\text { Per cent }\end{array}$ & $\begin{array}{c}\text { Ratio of } \\
\text { creatinin to } \\
\text { total nitrogen }\end{array}$ \\
\hline 1977 & Behrend & 4.86 & 10.50 & 4.01 & $1: 2.6$ \\
\hline 1978 & Oxo & 6.80 & 13.37 & 4.82 & $1: 2.8$ \\
\hline 1979 & Steero & 6.73 & 13.30 & 6.14 & $1: 2.2$ \\
\hline 1980 & Burnham & 1.41 & 5.0 .3 & 2.10 & $1: 2.4$ \\
\hline 1981 & Sunbeam & 1.23 & 5.39 & 2.10 & $1: 2.6$ \\
\hline 1982 & Armour & 2.43 & 10.94 & 4.19 & $1: 2.6$ \\
\hline 1983 & Morris & 5.78 & 12.57 & 5.82 & $1: 2.2$ \\
\hline 1984 & Standard & 2.73 & 11.88 & 2.84 & $1: 4.2$ \\
\hline 1985 & Liggitt & 2.37 & 12.18 & 2.83 & $1: 4.3$ \\
\hline 1986 & Knorr & 7.14 & 14.75 & 6.36 & $1: 2.3$ \\
\hline
\end{tabular}

laboratory. The latter contained sufficient salt to give a satisfactory taste to the cup of bouillon. The

i Bull. 107, Rev., Bureau of Chemistry, U. S. Dept. Agr.

a m. J. Phys., 18, 397 (1907).

3 Private communication.

4Z. Nahr. Genussm., 23, 577 (1912). 
results showed that 65 per cent of sodium chloride is sufficient to be added to a cube.

The figures for total creatinin vary according to the amount and kind of the meat extract present. The total creatinin inciudes the original creatinin of the cube and the creatin which has been changed to creatinin in the autoclave. As both substances are structurally closely related, and have a common origin in the creatin of the muscle, only the figure for total creatinin is given in this table. The determination of creatinin is very important in this work as it is of value in showing how much meat extract was used in preparing the cube. According to Seiger, ${ }^{1}$ if we place the creatinin content of meat extract at 6 per cent, then bouillon cubes should contain the following amounts of creatinin:

$\begin{array}{cc}\text { Meat extract used } & \text { Creatinin contained } \\ \text { Per cent } & \text { Per cent } \\ 25 & 1.5 \\ 20 & 1.2 \\ 15 & 0.9 \\ 10 & 0.6\end{array}$

The creatinin determination is applied to the water solution of the cube or meat extract. As noted ${ }^{2}$ by the writer before, there is not sufficient protein present in ordinary meat extract to interfere with the creatinin test. Geret ${ }^{3}$ has recently stated that the meat extract content of different cubes, based on the analyses of Liebig's meat extract, varies from 20 to 25 per cent for the superior cubes while the inferior cubes contain no creatinin. He also stated that gelatin increases the creatinin results. In a previous publication the writer stated that egg albumen and Witte's peptone, when added to solutions containing creatinin, decreased the creatinin result. The figures on which these statements are based were obtained by the Benedict-Myers method. It is likely that solutions of creatin containing gelatin or egg albumen, when evaporated to dryness or otherwise treated, would give high creatinin figures due to caramel or other colored products formed during the process, which might account for the high figures obtained by Geret.

Meat extract contains a higher per cent of total nitrogen than plant extract; therefore, a cube prepared largely from meat extract has a higher total nitrogen content than one prepared largely from plant extract. A good cube is indicated by high creatinin and high nitrogen figures. The results obtained by precipitation with absolute alcohol in hydrochloric acid solution, as outlined above, show that a larger per cent of nitrogen is precipitated in a high-grade than in a low-grade cube, and the figures are of some value in determining how much meat extract has been used in the preparation of the cube. The nitrogen precipitated by absolute alcohol in hydrochloric acid is not appreciably affected by the sodium chloride present. The acidity figures are of little value in determining the nature of the constituents present in a bouilion cube.

1 Konserven Zig., 48, 378 (1912).

2 J. Am. Chem. Soc., 31, 673 (1909).

${ }^{3}$ Z. Nahr. Genussm., 24, 570 (1912).
The phosphoric acid $\left(\mathrm{P}_{2} \mathrm{O}_{5}\right)$ results, especially when calculated to a water, fat, and ash-free basis, show higher figures for the superior cubes than for the inferior ones. The value of the phosphoric acid $\left(\mathrm{P}_{2} \mathrm{O}_{5}\right)$, total nitrogen and total creatinin results are more apparent on the water, fat, and ash-free basis than on the original basis. The creatinin-total nitrogen ratios show little in regard to the composition of the cubes, as a low creatinin figure due to the use of a small amount of meat extract, and a low total nitrogen figure due to the use of a large amount of plant extract would be found in the same product. From a survey of Sudendorf's analyses of cubes collected on the German market it is apparent that the cubes sold on the market in this country are very similar in composition to those on the German market, that is, both consist of a large amount of salt, together with smaller amounts of meat and plant extracts.

\section{SUMMARY}

Bouillon cubes on the market at present consist of about 5 per cent of water, I to 4.5 per cent of ether extract (fat), and 5o to 74 per cent of ash which is practically all sodium chloride. The nitrogen bodies and undetermined organic material amount to 20 to 40 per cent. The phosphoric acid $\left(\mathrm{P}_{2} \mathrm{O}_{5}\right)$ varies from 0.4 to 1.8 per cent, the total nitrogen from 2.I to 3.6 per cent, and the total creatinin from 0.49 to I. 67 per cent.

A cube prepared largely from meat extract gives high total phosphoric acid.$\left(\mathrm{P}_{2} \mathrm{O}_{5}\right)$, total nitrogen, and total creatinin figures. The amount of nitrogen precipitated by absolute alcohol and hydrochloric acid is also markedly higher than in a cube containing much plant and little meat extract.

Bouilion cubes are extensively advertised and are sold on account of their flavoring and stimulating properties, rather than for any slight food value they may possess. The large per cent of sodium chloride, which need not exceed 65 per cent, is used to furnish body to the cube and to give a salty taste to the cup of water in which the cube is dissolved.

Bouillon is a clear broth, the basis of which is meat; consequently a true bouillon cube should show high creatinin and high total nitrogen figures, and should be prepared entirely, or largely from meat stock or meat extract in addition to the salt and fat present. Several of the cubes on the market contain much more plant than meat extract and are not entitled to the name "bouillon" unless modified.

BUREAU OF CHEMISTRY

U. S. Department of Agriculture WASHINGTON, D. C.

\section{THE INFLUENCE OF BRAN-EXTRACTS ON THE BAKING QUALITIES OF FLOUR}

By H. L. White

Received September 6, 1913

It is generally recognized that bran and shorts contain valuable food constituents such as fat, carbohydrates other than cellulose, mineral matter and some nitrogenous material. Attempts have been made to improve the bread-making qualities of a flour, by in- 